\title{
Os excluídos da Arca de Noé*
}

AMADO LUIZ CERVO**

A opinião púbica em geral e a maioria dos especialistas em relações internacionais consideram a fase atual da evolução do capitalismo, denominada de globalização pela literatura, o caminho natural em direção ao mundo ideal. Os críticos da globalização sobrevivem, porém representam minoria nos meios políticos e acadêmicos. Argemiro Procópio, professor de longos anos da Universidade de Brasília, não se situa nem entre os entusiastas nem entre os críticos. Vai além, ao reunir uma plêiade de intelectuais de estirpe, da elite mundial, que solta um grito de indignação em uma seqüência de textos originais sobre o tema da moda. Os excluídos da Arca de Noé, os excluídos do sistema internacional contemporâneo, são atualmente as massas da periferia, mas serão, no futuro, todos os povos, caso não se conserte o rumo da globalização.

A indignação mantém seu ímpeto quando se derrama sobre as interpretações da História acerca das origens do sistema internacional atual, sobre a utilização devastadora dos recursos naturais que se exaurem, sobre a ação imperialista norte-americana contra o Iraque atrás do petróleo, um recurso natural escasso, sobre as populaçóes da Amazônia, cuja sorte o multilateralismo regional não favorece. A indignação vai se amainando quando se analisa o pensamento latino-americano aplicado às

\footnotetext{
* PROCÓPIO, Argemiro (org.). Relações internacionais: os excluídos da Arca de Noé. São Paulo: Hucitec, 2005, 328 p., ISBN 85-271-0665-5.

** Professor titular de História das Relaçôes Internacionais da Universidade de Brasília - UnB (alcervo@unb.br).
} 
relações internacionais e, enfim, a transição da globalização eurocêntrica para a bipolar no período que se estende entre as duas guerras mundiais. Os intelectuais que escrevem o fazem, em geral, na primeira pessoa, querendo significar discordância e autoridade. Posicionam-se distantes dos cânones do conhecimento disponível, de uma vasta e erudita literatura mundial que, aliás, dominam e manipulam com desenvoltura. O livro organizado pelo professor de relações internacionais da Universidade de Brasília desperta o apetite de quem procura os vírus que se escondem no âmago do mundo atual.

André Gunder Frank, em um texto que pode ser tomado como seu testamento acadêmico porque foi entregue ao organizador do livro pouco antes de sua morte, recua a origem do sistema mundial contemporâneo para cinco mil anos atrás. Recusa as interpretações que espalharam a visão da historiografia eurocêntrica, particularmente a obra braudeliana, acerca da economia-mundo de ascendência ocidental, em construção desde o século XVI. Para Gunder Frank, a Europa e o Ocidente já foram periferia de um mundo em que a ascendência coube a outras civilizaçōes, capazes de melhor fazer comércio e acumular o capital.

Franz Hinkelammert prolonga o raciocínio anterior, expondo a face contemporânea do sistema. Erigida em paradigma da globalização pela compulsão do indivíduo que se aliena ao mercado em competitividade, a eficiência é um suicídio. Indústria e agricultura exaurem suas fontes de vida, a terra e o homem. Por que não exorcizar os demônios da eficiência com valores éticos? Por que não consertar o quantitativo capitalista pelo qualitativo humano? E não pela exploração de uns sobre outros, pela salvação do centro mediante o sacrifício da periferia, como atualmente se observa.

Samir Amin ilustra a evolução do imperialismo - a palavra lá está! - da tríade US-UE-Japão para o unilateralismo norte-americano. Utilizando a "lei do valor mundial", a tríade quer controlar o sul com o fim de manter a "transfusão" para si, no caso, o petróleo. A Europa assiste, feliz, à ação dos Estados Unidos no Oriente Médio, incapaz de se descolar do liberalismo e do imperialismo da potência hegemônica enquanto não descobrir, em nome de sua própria cultura, outros eixos sobre os quais montar sua autonomia de relações internacionais. 
Elmar Altvater recorre ao conceito de natureza e à relação entre homem e natureza, via trabalho, em Karl Marx, para vislumbrar uma solução ao problema ecológico contemporâneo. A natureza constitui um conjunto de recursos sem limite a serem transformados pelo trabalho. Marx não percebe o fato de ser o trabalho um processo ao mesmo tempo produtivo e destrutivo. Mas seu conceito de relação natureza-homem ainda serve como o conceito mais adequado para fundar o trato do meio ambiente. Sem guerras por recursos escassos e sem injustiças em sua distribuição. O velho Marx ajuda a salvar a ecologia de um mundo a caminho da perdição.

Argemiro Procópio pinta um quadro barroco da Amazônia. A biopirataria converteu-se em fonte de acumulação dos países ricos. $\mathrm{Na}$ região vicejam a pobreza, o banditismo e a disputa pela terra. Narcotráfico e biotráfico se conjugam em modalidades distintas de um mesmo crime. Percebem-se junto aos países que compóem a bacia amazônica a escassez de segurança humana e de democracia e o excesso de tolerância diante da exclusão social. O Tratado de Cooperação Amazônica e sua Secretaria Permanente, recentemente instalada, malograram ao tentar soluções multilaterais para esses problemas. Não há solução sem que os governos da região inventem novo multilateralismo, com reforço do papel do Estado e plano de segurança concertado.

Raúl Bernal-Meza traça o itinerário do pensamento latino-americano aplicado às relações internacionais. Argumenta que a primeira versão crítica à economia política ricardiana correspondeu ao pensamento da Cepal, com sua visão de mundo dual, dividido entre centro e periferia, e de estruturas complementares permanentes que tendiam a perpetuar a desigualdade das duas partes. Passa depois pela teoria do desenvolvimento, pelos enfoques da dependência e chega ao neoliberalismo e à crítica da globalização. $\mathrm{O}$ texto expõe tanto as teorias quanto as estratégias de relações internacionais, com ênfase no pensamento argentino e na escola de Brasília.

Sem preocupar-se com a coerência epistêmica acerca do conjunto dos textos reunidos pelo organizador do livro, o grito dos indignados, Virgílio Caixeta Arraes chama, contudo, a atenção do leitor para a transição do sistema internacional entre as duas guerras mundiais - um 
período de crise que a Liga das Naçôes administra mal - em direção a algo novo, a transição do declínio europeu à emergência dos flancos, o que acabará por mudar a correlação das forças envolvidas no controle das relações internacionais contemporâneas.

Recebido em 4 de maio de 2005 Aprovado em 4 de julho de 2005 